\title{
The Social Self of Whitehead's Organic Philosophy
}

\section{Olav Bryant Smith}

\section{(2) OpenEdition}

\section{Journals}

Electronic version

URL: http://journals.openedition.org/ejpap/935

DOI: 10.4000/ejpap.935

ISSN: 2036-4091

\section{Publisher}

Associazione Pragma

\section{Electronic reference}

Olav Bryant Smith, «The Social Self of Whitehead's Organic Philosophy », European Journal of Pragmatism and American Philosophy [Online], II-1 | 2010, Online since 01 July 2010, connection on 10 December 2020. URL : http://journals.openedition.org/ejpap/935 ; DOI : https://doi.org/10.4000/ ejpap.935

This text was automatically generated on 10 December 2020.

\section{c) $(1) \Theta$}

Author retains copyright and grants the European Journal of Pragmatism and American Philosophy right of first publication with the work simultaneously licensed under a Creative Commons AttributionNonCommercial-NoDerivatives 4.0 International License. 


\title{
The Social Self of Whitehead's Organic Philosophy
}

\author{
Olav Bryant Smith
}

1 Alfred North Whitehead's philosophy has commonly become known as process philosophy. Whitehead himself regarded his philosophy as the philosophy of organism. His organic philosophy is understood through various types of process that occur in the becoming of actual organic entities in relationship with one another. Whitehead's conception of the self is one that provides an alternative foundation for psychology, helps to make sense of personal identity over time amidst a series of changing experiences, and offers a ground for understanding an ethic based on shared bonds between self and world. The mind-body problem is solved in the philosophy of organism, and a ground for understanding the lived body is provided.

This paper begins with Whitehead's deconstruction of the modern analysis of the self, and then discusses in turn Whitehead's "reformed" ontology and theory of perception, the becoming of a single occasion of experience, the development of societies of occasions of experience, the creation of self-identity over time as a society displaying a selective pattern or "unity of style." The paper concludes with a discussion of this social self, in the context of evolution, displaying an enjoyment and expression of lasting value through a series of fleeting activities of individual occasions of experience.

***

3 Whitehead's philosophy of organism would not have been created were it not for an analysis of the relations between the self and world. In what Whitehead termed his reformed subjectivist doctrine, he begins as Descartes did with the analysis of an act of experience, and then searches for an adequate model of the self and its experience.

Whitehead believed that modern philosophy's difficulties stem from a worldview that he referred to as Subjectivist Sensationism. Previous models of the self had been thrown off by the stress laid upon one, or other, of three misconceptions: 
The substance-quality doctrine of actuality.

The sensationalist doctrine of perception.

The Kantian doctrine of the objective world as a construct from subjective experience. (Whitehead 1978: 156) nature, the Greeks' ontology of qualities inhering in underlying substances were a direct result of analyzing subject-predicate propositions where the subjects were place-holders for ascribed predicates. Subjects endured in narratives through numerous predicative changes, and thus, substances endured while experiencing only qualitative changes over time. So, on the modern theory, the self's perception of the environing world, (the self being such an enduring substance), was sensationalist, with only such predicative descriptions being perceivable through the senses. The German idealist movement then began with Kant's model of the self beginning from such a subjective sensationalist starting point, and expressing an objective world resulting from that experience.

The combined influence of these allied errors has been to reduce philosophy to a negligi- ble influence in the formation of contemporary modes of thought. Hume himself introduces the ominous appeal to 'practice' - not in criticism of his premises, but in supplement to his conclusions. Bradley, who repudiates Hume, finds the objective world in which we live, and move, and have our being 'inconsistent if taken as real.' Neither side conciliates philosophical conceptions of a real world with the world of daily experience. (Whitehead 1978: 156)

Whitehead was searching for a model of the self and its experience of the world that was adequate to our experience. Hume's phenomenal theory, as Hume himself attests, had to be set aside when he got up from his desk in order to get on practically with life. Idealists, and other postmodern approaches that accept Kant's model of the synthesis of the self's experience from the subjective to an objective construction, find the external world to be somewhat illusory. Whitehead did not believe we can live on the basis of either model. $\mathrm{He}$ believed that our theory should support our practices, or be set aside as inadequate.

This, more than anything else, is the basis of what I will call Whitehead's speculative pragmatism. Whitehead was certainly not the only speculative pragmatist. Whitehead was influenced by James's speculation, and though he knew little or nothing of Peirce from what we can tell, Charles Hartshorne later began to point out the marked parallels between Whitehead and Peirce. ${ }^{1}$

8 The model of subjectivist sensationism is a set of twin principles, as Whitehead saw it.

9 On the one hand, there was an ontological analysis that Whitehead referred to as the subjectivist principle, which in the modern form saw the self's experience as analyzed purely in terms of the sense impressions. ${ }^{2}$ The second doctrine, which whitehead called the sensationist principle, said that the subject's experience lacked what Whitehead called subjective form. ${ }^{3}$

10 The subjectivist principle is rooted in

three premises: (i) The acceptance of the 'substance-quality' concept as expressing the ultimate ontological principle. (ii) The acceptance of Aristotle's definition of a primary substance, as always a subject and never a predicate. (iii) The assumption that the experient subject is a primary substance. (Whitehead 1978: 157)

11 Whitehead rejected all three of these beliefs.

12 Plato and Aristotle, he believed, came to accept this viewpoint because of their overconfidence in the power of everyday language to disclose the nature of reality. It is 
all too natural to move from descriptions of the world in terms of subject and predicate to a description of the nature of reality as qualities inhering in underlying enduring substances.

13 Analyzing the world through the lens of subject-predicate propositions, these philosophers made a distinction between universals and particulars, with the subjects of these propositions becoming known as primary substances, or what Whitehead would call actual entities, and the predicative qualities being recognized as universals.

The last point in this set is that self-analysis in modern philosophy took the experiencing subject to be one of these actual entities that was an enduring substance standing by itself apart from other actual entities in the world. Whitehead said that Descartes took it one step further in that direction by declaring that such substances "required nothing but themselves to exist" (Whitehead 1978: 159).

Whitehead gives Descartes credit for making "the greatest philosophical discovery since the age of Plato and Aristotle" (Whitehead 1978: 159) when he developed the subjectivist bias in philosophy and insisted that philosophy begin with the analysis of self-experience. But it was left to others, such as James and Bergson, to begin to put the subjectivist bias more fully into practice. Descartes missed the boat, for as Whitehead put it:

But like Columbus who never visited America, Descartes missed the full sweep of his own discovery, and he and his successors, Locke and Hume, continued to construe the functionings of the subjective enjoyment of experience according to the substance-quality categories. (Whitehead 1929: 159)

Rather than relying on the analysis of ordinary language, and the categories derived from it, Descartes and the later modern philosophers including Kant, should have taken subjective analysis more seriously and developed what might be called existential categories based more fully on, and therefore more adequate to, our actual experience.

These subject-substances, never being predicates, were completely separate and distinct entities. They lacked an objective element. Unlike our everyday experience in which the boundaries between us, our bodies, and the world beyond are blurred, the subjectsubstance ontology led to a doctrine of merely external relations of entities abstractly separated from one another.

This subject-substance ontology was then fatally combined with a sensationist epistemology. Whitehead initially discusses this sensationist principle in terms of "the bare subjective entertainment of the datum, devoid of any subjective form" (Whitehead 1978: 157). The importance of every element of this definition, just like the definition for the subjectivist principle, only unfolds over the next few pages of Whitehead's explanations. The sensationist principle, like the subjectivist principle, has two parts. The first is again methodological, for Whitehead approves of the general modern approach to the problem.

A theory of knowledge was also needed. Again philosophy started on a sound principle, that all knowledge is grounded on perception. Perception was then analyzed, and found to be the awareness that a universal quality is qualifying a particular substance. Thus perception is the catching of a universal quality in the act of qualifying a particular substance. (Whitehead 1978: 158)

Whitehead agrees that the development of an adequate theory of perception was the place to begin. ${ }^{4}$ The problem, however, is that it was a "doctrine of mere sensation" (Whitehead 1978: 157). This was Locke's blank slate upon which sense impressions, detached from objective actual entities, fall. The result of this subjectivist sensationism was the mind-body problem and skepticism about our interaction with a real, objective world. 


\section{米}

20 subjective entertainment of the datum," he meant that such perception was deemed to be
completely subjective. There was no objective element, and this is part of what led to the modern difficulties in philosophy. Whitehead believed that "Descartes' discovery on the side of subjectivism requires balancing by an 'objectivist' principle as to the datum for experience" (Whitehead 1978: 160). Thus, Whitehead proposed a reformed subjectivist principle that begins, as Descartes did, with an analysis of the act of experience, but recognizes an objective datum in that experience. For "common sense," Whitehead commented, "is inflexibly objectivist" (Whitehead 1978: 158).

entities in interaction with one another. We emphasize "the green leaf" as it is lifted up to consciousness and leave behind the vague awareness of the activities that result in the appearance of a green leaf (Whitehead 1978: 167). Whitehead, by contrast, wanted to lift the veil off of unconscious experiences of connection to the world and our past selves. He wrote:

The philosophy of organism is the inversion of Kant's philosophy. The Critique of Pure Reason describes the process by which subjective data pass into the appearance of an objective world [...]. For Kant, the world emerges from the subject; 
for the philosophy of organism, the subject emerges from the world - a superject

rather than a subject. (Whitehead 1978: 88) environment as they condition our present moment of becoming. But these causa influences are filtered through our body and we lift and arrange sense data to higher levels of con sciousness in order to picture and understand these influences, but those pictures are abstractions from the real process. Through our encounters with the environing world, we come to relate our sense impressions with what has been perceived as causally efficacious through what Whitehead calls symbolic reference (Whitehead 1978: 168). 
I would fain ask those philosophers, who found so much of their reasonings on the distinction of substance and accident, and imagine we have clear ideas of each, whether the idea of substance be derived from the impressions of sensation or reflection? If it be conveyed to us by our senses, I ask, which of them, and after what manner? If it be perceived by the eyes, it must be a colour; if by the ears, a sound; if by the palate, a taste; and so of the other senses. (Hume 1896: 15-6)

Whitehead points to the way in which Hume takes it as given that we see with our eyes, hear with our ears, taste with the tongue, and so on. According to Hume's own standards, displayed in this passage to critique the idea of substances, he should have no recourse to discussing such withness of the body in relationship to perception of the external world. We have no sense impressions of this "withness" (Whitehead 1978: 118).

We also, Whitehead insists, have a sense of intimate identity with our own bodies.

As to the direct knowledge of the actual world as a datum for the immediacy of feeling, we first refer to Descartes in Meditation I, "These hands and this body are mine"; also to Hume in his many assertions of the type, we see with our eyes. Such statements witness to direct knowledge of the antecedent functioning of the body in sense-perception. Both agree - though Hume more explicitly - that senseperception of the contemporary world is accompanied by perception of the withness of the body. It is this withness that makes the body the starting point for our knowledge of the circumambient world. We find here our direct knowledge of causal efficacy. Hume and Descartes in their theory of direct perceptive knowledge dropped out this withness of the body; and thus confined perception to presentational immediacy. (Whitehead 1978: 81)

Hume even speaks of degrees of force and vivacity of various sensations that derive from this withness of the body, thus suggesting that he is aware of the causal efficacy of the source of these sensations. ${ }^{6}$ The phenomenal account of knowledge is nearly always supplemented in some manner by an appeal to an objective source of those sensations. Whitehead confronts this head-on when he writes of perception in the mode of causal efficacy

In summation of this section, then, for whitehead, there are two primary modes of perception: the mode of presentational immediacy and the mode of causal efficacy. The highly abstract picture-world of presentational immediacy is then related to the more vague feelings of causal power coming from our past experiences and encounter with an environing world through the process of symbolic reference.

Error enters our accounts through this symbolic reference. No one can live as if there were not causally efficacious entities in our environing world, and no one can seriously challenge my sincere reports of the sensations that I perceive, as sensations. But the matching of sensation to a causally efficacious source, and the explanation of the real nature of that source, may indeed be questioned, fleeting activities of individual occasions of experience.

\section{米}

There are two senses of the self that we are dealing with here: the spatial and temporal. What I am calling the spatial aspect of the self involves withness and mineness of the body. In other words, it involves a certain degree of identity of the self with the body.

This could be interpreted from a Cartesian point of view. Descartes understood the physical world from the point of view of the physics of his time. The body, on that view, is 
made up of physical substances that are merely extended. They are "vacuous" as Whitehead put it (Whitehead 1978: xiii). They have no experience and no purpose. These bits of matter simply are. Any interaction between these physical substances is external, like billiard balls bumping into one another. The view of a collection of such physical substances is the interpretation of "Nature lifeless" (Whitehead 1938: 127-47).

The view of the universe as consisting of bits of matter that are extended, inert, lifeless, valueless, and purposeless, Whitehead termed scientific materialism (Whitehead 1925: 17). According to scientific materialism, the world consists of bits of matter, understood as enduring substances, in empty space. Each bit of matter occupies a definite location in that space that is occupied by no other entity. Each substance was qualified by certain qualities. Empty space was understood as an unchanging container for these bits of matter.

This is the grand doctrine of nature as a self-sufficient, meaningless complex of facts. It is the doctrine of the autonomy of physical science. It is the doctrine which [...] I am denying. (Whitehead 1938, 132)

41 This view has not survived scientific challenge through the centuries, however. Colors and other sense data that are most important to us as human beings and artists were the first to be dropped from the picture of the way things really are in the universe. Some philosophers distinguished between primary and secondary qualities. Kant went to so far as to suggest that we cannot ever know the way things themselves really are. The theory of empty space has disappeared with our understanding of the transmission of light and sound through the universe. Newton's idea of forces, or stresses, such as gravitation, challenged the notion of merely external relations before quantum mechanics did. And in the end, matter has been equated with energy. As Whitehead wrote:

The state of modern thought is that every single item in this general doctrine is denied, but that the general conclusions from the doctrine as a whole are tenaciously retained. The result is a complete muddle in scientific thought, in philosophical cosmology, and in epistemology. But any doctrine which does not implicitly presuppose this point of view is assailed as unintelligible. (Whitehead 1938: 132)

The assailants Whitehead had in mind were those early- to mid-twentieth-century philosophers who embraced scientific materialism. Whitehead's metaphysics were rooted in his understanding of these developments in science that transcend scientific materialism, and he saw an opportunity to bridge the gap in the mind-body problem.

By analogy, Whitehead hypothesized an extension of the Jamesian notion of drops of experience from human beings to all actual entities. This goes all the way down the chain of being to atomic and subatomic entities. Given the developments of electromagnetic and quantum physics, he believed that it made more sense to assume that there is some degree of experience in every entity than to assume there is none on the lower end of being and that somehow, miraculously, experience sprang from nowhere.

He did not believe that aggregations of such occasions of experience such as rocks or bone, etc., showed any sign of having experience, but he believed that the actual entities that comprised them did. A particular muscle, for example, might not have a unity of experience that is aware of such collective experience, but the cells that make up the muscle have such experience individually. He called an aggregation of such occasions of experience a nexus (plural nexus). He described them as "public matters of fact" because 
due to their large numbers they appear to us as real individual facts of togetherness. Their togetherness is due to mutual prehensions of one another (Whitehead 1978: 22-4).

Whitehead did not want to use the word apprehension to describe the interrelations of these actual occasions of experience, because that might mislead people into thinking that he thought all such occasions were conscious. He did not. He saw consciousness as a particularly high order of experience in very complex organisms. He chose the word prehension to cover all such experiences of togetherness, including unconscious ones. These prehensions denote the internal relatedness of one entity toward another. Some nexus display "social order" due to shared characteristics mutually prehended.

This mutual prehension of shared characteristics promotes intensity in the nexus. Whitehead called these nexus with social order societies and described four major kinds of society: enduring objects, corpuscular societies, structured societies, and living societies.

Some nexus can be analyzed apart from the wider social order in terms of their purely temporal relatedness through a series, or 'historic route.' Whitehead calls these enduring objects. Whitehead says that they could, loosely, be called persons because of the personal order that is sustained over time in them. In fact, persons or selves are enduring objects, but not all enduring objects are persons, if by 'person' we mean conscious, or selfconscious, beings. Corpuscular societies are multiple strands of enduring objects. Structured societies have a subordinate society within a dominant society. And living societies are structured societies with living nexus.

Given this nesting of societies, one within the other, in Whitehead's view of the world, one could say that the universe is a vast network of experiential entities in relationship with one another. Hence the term panexperientialism has also been used to describe one of the dominant characteristics of Whitehead's philosophy of organism. Evolution, according to Whitehead, has been in the direction of more and more complex and creative unities of experience over time. For this reason, he was critical of the idea that evolution is driven by the principle of survival of the fittest.

A rock is nothing else than a society of molecules, indulging in every species of activity open to molecules. I draw attention to this lowly form of society in order to dispel the notion that social life is a peculiarity of the higher organisms. The contrary is the case. So far as survival value is concerned, a piece of rock, with its past history of some eight hundred million years, far outstrips the short span attained by any nation. The emergence of life is better conceived as a bid for freedom on the part of organisms, a bid for a certain independence of individuality with self-interests and activities not to be construed purely in terms of environmental obligations. The immediate effect of this emergence of sensitive individuality has been to reduce the term of life for societies from hundreds of millions of years to hundreds of years, or even to scores of years. The emergence of living beings cannot be ascribed to the superior survival value either of the individuals, or of their societies. (Whitehead 1927: 64-5)

Evolution, Whitehead insists, would have stopped at rocks if the main issue were survival of the fittest. The main issue is something else that he once called the art of life (Whitehead 1929: 4).

Human beings are a particularly complex society that is an example of a living society. The human body has adjusted over time to changes in the environment, allowing a dominant, personally ordered, enduring object, which we could refer to as the self, to emerge. The self is nested within a relatively friendly environment. With the body, it forms a society. The body is nested within a relatively friendly environment. With this 
environment, it forms a society. There are other human beings within that environment. The community of human beings forms a society. All of this relative security within relatively friendly environments provides the human being the luxury to experiment creatively with new ideas.

The problem of how the self, as mind, relates to the body is solved within this scheme. If every actual entity has some degree of experience, and the actual entities of the body form a society that is conducive to the development of the self, then the whole network is a communicative network of sorts. The cells of the body communicate with the cells of the brain. The cells of the brain communicate with the enduring object with personal order that we are referring to as the self. The enduring, sentient self as subject and agent within an environing network of communication is conditioned by that environment, and provides some direction to that environment in turn.

The personally ordered, enduring object that is the self is just one example among many kinds of enduring objects. An electron is an enduring object with very little complexity and very little change over time. It repeats a vibratory pattern along the thread of its personal history. The human self is more complex, but our analysis of an actual entity, with the self in mind, will touch on all actual entities in the process.

4 An enduring object is a purely temporal society. The self is an enduring object within the environment of a body that provides it protection and serves as a vehicle for action in the environing world.

5 As a temporal society, it is not a self-same enduring soul that is the same from birth to death. The question of personal identity must be addressed as part of this overall discussion. But before we get there, we should consider the nature of a single occasion of experience along the historical thread of such experiences that make up the purely temporal society that is the self.

Again, referring to James, Whitehead says that these occasions of experience come in "drops." Whitehead analyzes the phases of the becoming, or concrescence, of this occasion. Whitehead saw that he owed an important debt to Kant in this analysis of the synthetic becoming of a single act of experience. For Kant, as Whitehead saw it, is

the great philosopher who first, fully and explicitly, introduced into philosophy the conception of an act of experience as a constructive functioning, transforming subjectivity into objectivity, or objectivity into subjectivity; the order is immaterial in comparison with the general idea. (Whitehead 1978: 156)

57 Kant, of course, had argued that our knowledge of the objective world was produced through this constructive functioning out of a subjective experience. Whitehead's analysis of an act of experience is also about a constructive functioning in that act, but it goes from an initial encounter with the objective world, and produces a subjective account of it in the end.

There are three major phases of this organic model of becoming as a constructive function: conformal, aesthetic, and intellectual.

The first, or conformal, phase involves what Whitehead calls sympathetic, or conformal, feelings. The world, and particularly the objectification of an antecedent occasion with which the present occasion enjoys self-identity, is enjoyed in the sense of shared feeling, 
of feeling with. The entire universe, including the antecedent occasion in the personal order, is physically felt in its nature of being an efficient cause. This efficient cause enters into the becoming of every occasion of experience as a conditioning influence. In the case of some actual occasions, including that of the human self most particularly, there is inheritance of an aim. This aim can be repeated, thereby gaining intensity, eliminated, or modified in later phases of becoming.

The second phase of this becoming is an aesthetic supplementation introducing a valuation of the universe from the perspective of that new organic unity that is an occasion of experience. It is a phase of aesthetic appreciation of inherited rhythms and patterns in its environing world, including the intensities of the antecedent occasion in its own personal history. Some elements are valued highly, and some elements are swept aside as unwanted. It is a phase of emotional encounter with the world, and results in adversions and aversions. Whitehead says that if this phase is particularly strong, then the third phase will be negligible.

The third phase of intellectual supplementation introduces a contrast of what is with what could be. It is here that the potential ways of being in the world (which whitehead terms eternal objects) that have already been actualized are contrasted with the potentials that could have been realized, or might yet be realized. These potentials flood into the second phase of an act of experience, but are not given attention as potentials. They are simply felt, and appreciated or depreciated. It is in the third phase of intellectual supplementation that the potentials are given attention as such. This is the phase of mind, or consciousness, in Whitehead's thought. With James, he does not want to reify consciousness. It is but another way the actual occasion of experience feels the world. This consciousness is not a substance.

This entire process is also guided by an initial aim that becomes, in the later phases, a contrast between the ideal for that situation, and the feelings and functioning of the occasion that is in the process of becoming. Caught in the interplay between personal feelings of the actual world of that occasion of experience and a vaguely felt perception of the ideal for that situation, decisions are made. The newly becoming occasion modifies the course, and projects a modified aim for its subsequent occasion of experience.

There is a third factor in that decision that must also be considered: an inherited aim. Whitehead says there are two forms of process, and this becoming of a single occasion of experience is one of those forms. The other form is what he often terms the transition. The individual occasion of experience begins in conformal unity with the antecedent occasion in a historical thread of occasions. The occasion of experience ends as what Whitehead terms a superject, objectifying itself for conformal unity in a subsequent occasion, and thus providing an inherited aim for the subsequent occasion of experience.

In the last section, this paper emphasizes the finite constructive act of experience that begins with the inheritance of an aim under the influence of an environing world, an initial ideal aim that guides the process of becoming as a final cause, and ends with a final adjustment of personal aim in the context of that actual world. 

coming one after the other was not sufficient to explain our sense of self. He addressed this problem directly.

Personal Identity is a difficult notion. It is dominant in human experience: the notions of civil law are based upon it. The same man is sent to prison who committed the robbery; and the same materials survive for centuries, and for millions of years. We cannot dismiss Personal Identity without dismissing the whole of human thought as expressed in every language. (Whitehead 1948: 94)

Personal identity, for Whitehead, is, in one sense, a new construction in every moment of new becoming. The solution that he offers to the resulting problem of identity has to do with the relationship of fact and value. The interaction of the world of fact and the world of value are central to Whitehead's understanding of the universe. It is value that persists over time, while the functional activity of the individual occasion of experience arises and perishes in a flash. These two worlds are bound together by Whitehead's concept of the idea. 
(The) ultimate character (of the Universe) has two sides - one side is the mortal world of transitory fact acquiring the immortality of realized value; and the other side is the timeless world of mere possibility acquiring temporal realization. The bridge between the two is the "Idea" with its two sides. (Whitehead 1948: 92) evolution is driven strictly by survival of the fittest. He does not dispute that the fit survive and that the weak perish. Rather, he points to the way in which the higher organisms do not survive as long as lower forms of existence. Rocks, for instance, survive for millions of years. There is another factor that has to be considered.

Why has the trend in evolution been upwards? The fact that organic species have been produced from inorganic distributions of matter, and the fact that in the lapse of time organic species of higher and higher types have evolved are not in the least explained by any doctrine of adaptation to the environment, or of struggle. (Whitehead 1927: 7)

The emergence of sentience on the classical view of evolution is itself puzzling. That is one of the reasons that drove Whitehead to speculate that it makes more sense to view some element of experience all the way down, however faint it might be at the bottom, rather than to wonder how it might have miraculously appeared later on. The whole of 
nature is organic, he concludes, and the notion of lifeless, inert, purposeless matter is based on our macroscopic views of aggregates of actual entities.

The upward trend has not primarily involved an adaptation to the environment, Whitehead notes.

In fact the upward trend has been accompanied by a growth of the converse relation. Animals have progressively undertaken the task of adapting the environment to themselves. (Whitehead 1927: 7)

The upward trend in evolution (which has involved an increasing capacity to manipulate the environment $)^{8}$ has been driven by an increase in the capacity to enjoy intensities of value.

[T]his active attack on the environment is a three-fold urge: (i) to live, (ii) to live well, (iii) to live better. In fact, the art of life is first to be alive, secondly to be alive in a satisfactory way, and thirdly to acquire an increase in satisfaction. (Whitehead 1927: 8)

This increase in satisfaction is an increase in the enjoyment of value. And Whitehead observes that the most effective societies "involve a large infusion of various sorts of personalities as subordinate elements in their make-up - for example, an animal body, or a society of animals, such as human beings" (Whitehead 1927: 94).

So, the human body is one such society that has evolved a variety of coordinated personalities for the purpose of greater intensities and enjoyment of value.

4 With Whitehead's philosophy of organism, it is clear that there is a solution of the mindbody problem. The self is part of a larger society that includes the body, and the entire society in some significant ways functions as one organism. It is so successful at this that we quite confidently speak of the body as being mine.

The self would not seem to be directly connected, however, to the environing world beyond the body. In fact, there is some question as to where Whitehead believed the self resides within the body. If we supposed that the self resides somewhere in the brain, though, then it would seem that the self only experiences and directly communicates with the cells of that part of the brain. Communication with the rest of the body would be indirect.

86 But the entire body is mine. Not just the cells with which I am most directly in communication. My explanation for this would be that the Whiteheadian body is not only a network of communication nested within the network of the greater environment, but it is (as Whitehead said) a society enjoying social order due to shared character. The shared character is made possible by a sympathetic bond of physical feeling at the beginning of each occasion of experience. While it is true that each occasion of experience may emphasize different aspects of those feelings to be heightened for its own expression of individuality, the bond establishes a common character.

By extension, we could say that the same is true for ever greater unities beyond the body. Whitehead at one point called the body a "complex amplifier" (1978: 119). The body not only relays signals from within the body, but also from outside the body. There is a filter. We do not pick up on anything in our environment without abstraction and simplification. We place emphasis on certain elements of our experience, and all of our sense organs do as well. But we have the possibility of developing the ability of retaining these sympathetic feelings with our environment through greater and greater ranges over time. 
88

hically, this is significant. The social self in Whitehead suggests that the development of sympathetic connections with the environment, including fellow human beings, is important in the development of shared value. An increased emphasis on these sympathetic bonds may lie not only at the heart of our ability to live well together as human beings, but also to manage our environment with care. ${ }^{9}$

\section{BIBLIOGRAPHY}

HARTSHORne C., (1984), Creativity in American Philosophy, NY, SUNY Press.

HUME D. (ed.) \& L. A. SELBY-BIGGE, (1896), Treatise of Human Nature, Oxford, Clarendon Press [originally published in 1739].

JAMES W., (1911), Some Problems of Philosophy, London, Longman's and Green.

MERLEAU-PONTY M., (1962), Phenomenology of Perception, tr. Colin Smith, N.Y., Routledge.

MERLEAU-PONTY M., (1995), Nature, ed. Dominique Séglard, tr. Robert Vallier, Evanston, IL., Northwestern U. Press.

SMITH O., (2004), Myths of the Self: Narrative Identity and Postmodern Metaphysics, N.Y., Lexington Books.

SMITH O. \& D. GRIFfin, (2003), “The Mystery of the Subjectivist Principle," Process Studies, 32 (1), 3-36.

WEISS P., (1980), “Recollections of Alfred North Whitehead," Process Studies, 10 (1-2), 44-56.

WHITEHEAD A.N., (1925), Science and the Modern World, N.Y., Free Press.

WHITEHEAD A.N., (1927), Symbolism, N.Y., Fordham U. Press.

WhiteheAd A.N., (1929) The Function of Reason, Princeton, Princeton U. Press.

WHITEHEAD A.N., (1938), Modes of Thought, N.Y., Free Press.

WhiteHEAD A.N., (1948), Science and Philosophy, Patterson, N.J., Littlefield, Adams.

WHITEHEAD A.N., (1978), Process and Reality: Corrected Edition, eds. David Ray Griffin \& Donald Sherburne, N.Y., Free Press [originally published in 1929].

\section{NOTES}

1. Hartshorne, along with Paul Weiss, worked as Whitehead's T. A. at Harvard while they were editing Peirce's collected papers. For one example of Hartshorne's discussions of Peirce and Whitehead, see the chapter on Whitehead in his book Creativity in American Philosophy (Hartshorne 1984: 103-13).

2. Whitehead's discussion of these matters was very confusing. There has been a lot of discussion through the years about how to untangle his ambiguity. I have written about it in my book (Smith 2004: 90-132), and a paper co-authored by David Ray Griffin (Smith \& Griffin 2003: 3-36). 
3. Whitehead called this the sensationalist principle, and some Whitehead scholars have shortened this to the sensationist principle.

4. It is easy to see why Merleau-Ponty would have seen a kindred spirit in Whitehead when he attempted to disclose the lived body through a new theory of perception. This is the work of Phenomenology of Perception (Merleau-Ponty 1962). More recently, Merleau-Ponty's lecture "The Idea of Nature in Whitehead," based on Whitehead's early philosophy of nature and metaphysical works, was posthumously published in Nature (Merleau-Ponty 1995: 113-22).

5. In this respect, modern science hearkens back to pre-Socratic natural philosophy and the attempt to understand the underlying nature of reality, not settling for easy answers as they appear to us on the surface of sense perception.

6. In a related manner, Locke said that his sense impressions come from 'something, he knows not what.' And Kant assumes there is a noumenal reality that is the source of these impressions.

7. Whitehead often referred to these ideas as eternal objects to distinguish them from Plato's ideas.

8. It is increasingly apparent that the ability of human beings to manipulate their environment may outstrip their wisdom to manage that manipulation with care. There may soon come a time when the drive to enjoy value in the short-term will come at the expense of long-term value or even survival.

9. Confucianism, for example, is based in part on the extension of identity through greater and greater ranges of sympathy. The infant identifies with the mother, and then with the immediate family. Over time, this sympathetic bond grows to neighbors and the community at large. There is the hope, in the end, that one might be develop the characteristic of ren, represented by the character of a person learning to live in harmony with others through this sympathetic bond.

\section{AUTHOR}

\section{OLAV BRYANT SMITH}

California State University, Chico 